
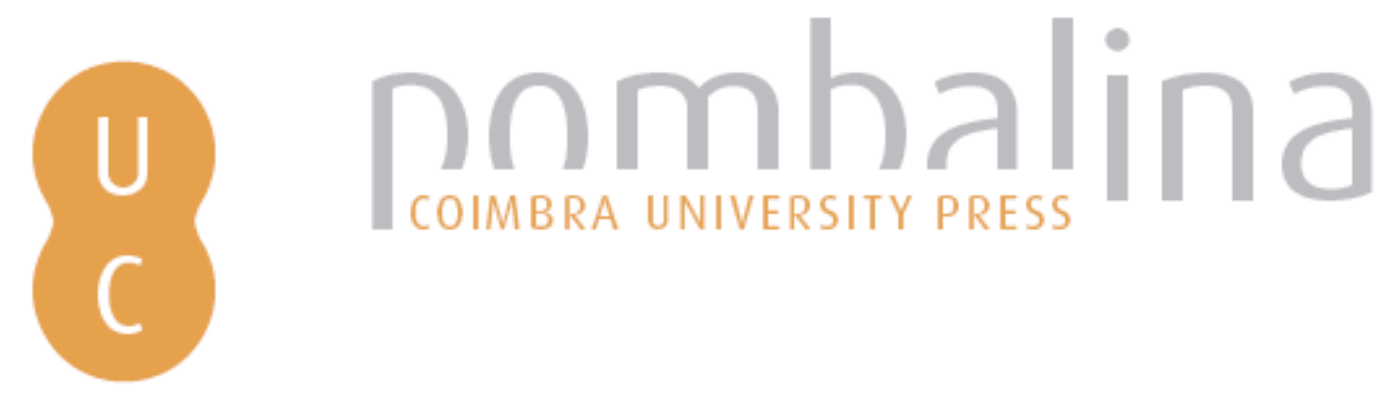

\title{
Amadorismo e profissionalismo na Grécia Antiga
}

Autor(es): $\quad$ Portela, Joana

Publicado por: Imprensa da Universidade de Coimbra

URL

persistente: URI:http://hdl.handle.net/10316.2/38368

DOI: $\quad$ DOI:http://dx.doi.org/10.14195/978-989-26-0371-1_6

Accessed : $\quad$ 26-Apr-2023 11:59:13

A navegação consulta e descarregamento dos títulos inseridos nas Bibliotecas Digitais UC Digitalis, UC Pombalina e UC Impactum, pressupõem a aceitação plena e sem reservas dos Termos e Condições de Uso destas Bibliotecas Digitais, disponíveis em https://digitalis.uc.pt/pt-pt/termos.

Conforme exposto nos referidos Termos e Condições de Uso, o descarregamento de títulos de acesso restrito requer uma licença válida de autorização devendo o utilizador aceder ao(s) documento(s) a partir de um endereço de IP da instituição detentora da supramencionada licença.

Ao utilizador é apenas permitido o descarregamento para uso pessoal, pelo que o emprego do(s) título(s) descarregado(s) para outro fim, designadamente comercial, carece de autorização do respetivo autor ou editor da obra.

Na medida em que todas as obras da UC Digitalis se encontram protegidas pelo Código do Direito de Autor e Direitos Conexos e demais legislação aplicável, toda a cópia, parcial ou total, deste documento, nos casos em que é legalmente admitida, deverá conter ou fazer-se acompanhar por este aviso.

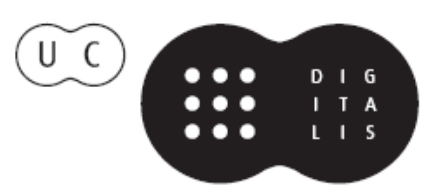


FRANCISCO DE OLIVEIRA

Coordenação

Ospírito Olímpico

no

novo milénio 


\section{AMADORISMO E PROFISSIONALISMO NA GRÉCIA ANTIGA}

Joana Portel a

Universidade de Coimbra

O espírito olímpico idealizado por Pierre de Coubertin, ao fundar os Jogos Olímpicos Modernos, assentava em alguns princípios fundamentais: a fraternidade entre as nações, o desenvolvimento harmonioso do Homem e o verdadeiro amadorismo. Estes ideais, segundo Coubertin, buscavam as suas raízes na ideologia olímpica da Grécia antiga.

Nas últimas décadas, o ideal olímpico proposto por Coubertin tem sofrido um retrocesso significativo no que respeita ao princípio do amadorismo. Nos Jogos Olímpicos de Séoul, realizados em 1988, já participaram nas diversas provas muitos atletas profissionaisO, e desde então, cada vez mais, são os atletas profissionais aqueles que competem e vencem nestes Jogos.

No inicio do novo milénio, uma pergunta se impõe: com a crescente profissionalização dos atletas olímpicos, estaremos hoje a afastar-nos ou a aproximar-nos, em termos ideológicos, do espírito olímpico da Grécia antiga? A controversa questão do amadorismo e do profissionalismo no mundo do desporto tem sido muito discutida ultimamente, não só no que se refere aos Jogos Olímpicos mais recentes, mas sobretudo às competições desportivas da Grécia antiga. (2)

0) A título de exemplo, podemos referir atletas como Cari Lewis ou Sergei Bubka.

(2) O amadorismo e profissionalismo nos agones da Antiguidade Clássica são amplamente discutidos por E.N. Gardiner (Greek Athletic Sports and Festivais, 1910; Athletes of the Ancient World, 1930), H.W. Pleket ("Games, prizes, athletes and ideology: some aspects of the history of sport in the Graeco-Roman world", 1975; "The participants in the ancient Olympie Games: social background and mentality", 1992) e D.C. Young (The Olympie myth of Greek amateur athletics, 1984; "How amateurs won the Olympics", 1988). 
Ao analisar retrospectivamente a questão do amadorismo e do profissionalismo na Antiguidade, devemos estar bem conscientes de que "amadorismo" e "profissionalismo" são conceitos modernos e, de alguma forma, anacrónicos quando os reportamos ao universo desportivo da Grécia antiga. O termo "amadorismo", significando a prática do desporto pelo desporto, sem dele retirar qualquer benefício ou pagamento, veicula um conceito ideológico muito recente, nascido em Inglaterra entre a elite vitoriana do século XIX(3).

A filosofia e o ideal de amadorismo parecem ser estranhos à natureza do desporto na Grécia antiga. Os Gregos não tinham nem o conceito nem o vocabulário do amadorismo e, de uma forma geral, estavam longe de fazer uma distinção entre atleta amador e atleta profissional como a fazemos hoje.

Actualmente, com a designação "atleta profissional", queremos significar o desportista que aufere proveitos materiais ou financeiros pela sua actividade desportiva, dedicando uma grande parte do seu tempo à prática do desporto e dele fazendo o seu modo de vida. Esta concepção moderna de atleta profissional parece ser alheia à ideologia da Antiguidade.

De facto, quando tentamos reconstruir a mentalidade do universo atlético da Grécia antiga, apercebemo-nos de que os atletas gregos não encaravam a sua actividade desportiva como uma profissão, ainda que se dedicassem a tempo inteiro à prática do desporto e daí recebessem dinheiro ou outros bens materiais. Ao contrário do que sucede actualmente, na Grécia antiga, os ganhos financeiros dos atletas profissionais não eram encarados como o rendimento obtido pelo exercício de uma profissão.

A razão de, na Antiguidade, uma carreira desportiva não ser considerada pelos próprios atletas como uma profissão, nem, consequente86 mente, uma forma de ganhar o sustento diário, não resulta de um ideal helénico de amadorismo. Explica-se pelo facto de a ideologia atlética do mundo grego ter sido estabelecida pelos primeiros atletas, membros de uma elite aristocrata que desprezava a ideia de exercer uma actividade

(3) Por iniciativa de Pierre de Coubertin, reuniu-se em Paris, em 1914, o Congresso Internacional que definiu o conceito de amadorismo no desporto. 
profissional, qualquer que ela fosse, para assim obter o seu sustento económico. Por esta razão, na ideologia própria dos atletas, a prática

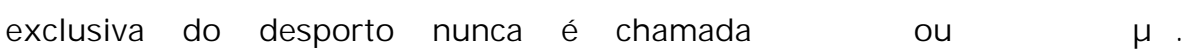
A definição moderna de desporto profissional e de profissionalismo teria, pois, surpreendido o atleta antigo, precisamente porque pressupõe uma atitude positiva relativamente ao facto de todas as pessoas terem um trabalho remunerado.

Assim se conclui que o emprego dos termos "amadorismo" e "profissionalismo" para descrever o universo social e ideológico do desporto na Grécia antiga pode levantar alguns problemas de anacronismo. Por isso, é fundamental definir previamente e com precisão o significado a atribuir a estas duas designações, de modo a que as possamos empregar retrospecticamente, como conceitos instrumentais, para caracterizar a realidade desportiva da Grécia antiga.

Assim, quer para os dias de hoje quer para a Antiguidade grega, entenderemos "amadorismo" como a prática desinteressada de uma actividade desportiva, que não requer do atleta uma dedicação exclusiva e a tempo inteiro, nem constitui para ele uma fonte de rendimento. Paralelamente, iremos empregar o conceito de "profissionalismo" para caracterizar uma situação em que o atleta, pelo exercício da sua actividade desportiva, é capaz de auferir um ganho financeiro continuado durante o período de tempo em que se dedica intensa e exclusivamente à prática do seu desporto.

Uma vez definidos os conceitos operatórios de amadorismo e profissionalismo, convém esclarecer ainda um outro aspecto, que diz respeito à sociologia e ideologia dos atletas gregos. Em termos sociológicos, não havia uma categoria específica de atletas olímpicos, nem, em termos ideológicos, uma mentalidade exclusiva dos Jogos Olímpicos. O ideal olímpico não estava confinado aos jogos realizados em Olímpia, mas estendeu-se aos diversos agones, pan-helénicos ou não. Os atletas olímpicos participavam igualmente em centenas de outros concursos desportivos ${ }^{(4)}$ e a ideologia atlética corrente era, portanto,

(4) Finley- Pleket (The Olympie Cames. 1976) estipulam em cerca de 50 os concursos desportivos para o ano 500 a. C, número que vai aumentando até atingir, aproximadamente, 300 no séc. I d. C. 
aplicável a todos os atletas, quer competissem ou não nos Jogos Olímpicos.

Feitas estas ressalvas iniciais, é agora altura de analisar, no âmbito da ideologia olímpica actual, alguns mitos, preconceitos e pressupostos modernos que se foram difundindo em torno do atleta antigo. Um desses mitos olímpicos, ainda hoje demasiado comum, é o mito do amadorismo grego nos Jogos pan-helénicos e em outras competições desportivas. Durante várias décadas do século $X X$, vigorou a ideia de que, na antiga Grécia, os atletas olímpicos eram verdadeiros amadores, praticando o desporto pelo desporto e competindo apenas por uma coroa de oliveira, símbolo de glória e aretê. Todavia, este é um mito moderno, nascido durante o século XIX, simultaneamente com o desenvolvimento do movimento amadorista entre a elite britânica. A tese do atleta grego amador, muito defendida e difundida pelo Olimpismo, só recentemente foi posta em causai ${ }^{5}$ ).

Efectivamente, durante muito tempo foi opinião aceite entre os historiadores modernos que os atletas gregos da época arcaica e clássica eram verdadeiros amadores e que a entrada do profissionalismo nas competições desportivas, especialmente na época helenística, levara ao declínio, ideológico e moral, dos Jogos. Esta tese foi largamente difundida, sobretudo por Norman Gardiner no princípio deste séculoi6). Este autor britânico, de origens aristocratas e de uma absoluta dedicação à contemporânea causa do amadorismo, atribuiu particular ênfase ao estudo do amadorismo e do profissionalismo nas competições desportivas da Antiguidade. Uma vez que a sua tese viria a fazer escola nos anos posteriores, contribuindo muito para alimentar o mito do amadorismo grego, convém que nos detenhamos agora sobre algumas ideias fundamentais deste autor.

Gardiner defende que no período arcaico da Grécia antiga todos os atletas eram de nascimento nobre e amadores genuínos. Todavia, de

(5) É sobretudo a partir de 1984, com a obra de David Young intitulada The Olympie myth of Greek amateur athletics, que o amadorismo grego começa a ser encarado como um mito olímpico moderno.

(6) Norman Gardiner, nas suas obras Greek Athletic Sports and Festivais (1910) e Athletics of the Ancient World (1930), contribui academicamente para a difusão da ideia de que o desporto grego experimentou uma fase ascendente marcada pelo amadorismo, a que se seguiu uma fase de declínio em consequência da profissionalização dos atletas. 
acordo com este autor, já no séc VI a.C. era possível detectar um elemento de potencial excesso nas honras atribuídas aos vencedores. A exagerada importância dada à excelência física e à obtenção de vitórias nos Jogos trouxeram consigo a especialização dos atletas e a dedicação exclusiva a um único desporto. Para Gardiner, é durante o século VI a.C. que começa a verificar-se uma competição excessiva, devido à multiplicação de atletas concorrentes e de prémios monetários, que progressivamente estavam a tornar a prática do desporto numa rentável fonte de lucros.

Consequentemente, no início do século $\mathrm{V}$ a.C., surge o tipo de atleta que participa no maior número de competições possível, movido apenas pela caça ao prémio. Este novo tipo de atleta, que Gardiner designa por "pothunter"(7), viaja de competição em competição para recolher prémios e fortuna. Durante o século $\mathrm{V}$ a.C., quando as recompensas materiais pela vitória se tornam muito aliciantes, começa a surgir a nova classe dos atletas profissionais. Segundo Gardiner, os atletas amadores vão sendo progressivamente substituídos pelos profissionais, tentados pelas enormes somas de dinheiro que poderiam ganhar com as vitórias. Por esta razão, defende o mesmo autor, nos inícios do século IV a.C., começa a verificar-se o declínio, o definhamento ideológico e a corrupção nas competições desportivas.

Gardiner atribui esse declínio ao aumento do número de atletas profissionais, maioritariamente oriundos - segundo ele - das classes sociais mais baixas, atraídos para as competições desportivas apenas pela sedução dos avultados prémios. Não obstante, o mesmo autor acreditava igualmente que, mesmo durante a fase do declínio, o antigo ideal aristocrático de amadorismo se mantinha nos Jogos realizados em Olímpia, e acreditava também que ao longo de todos os períodos da história grega houve sempre homens de elevada posição social competindo como genuínos amadores.

Estas ideias de Gardiner, embora tenham vigorado nos meios académicos durante várias décadas, têm sido ultimamente postas em

(7) Gardiner, Athletics of the Ancient World, Chicago, 1987, p. 101: "Early in the fifth century there arouse the 'pothunter', who spent most of his time travelling from city to city, picking up prizes." 
causa por vários historiadoresí8). Um dos ideais olimpistas mais veiculados na obra deste autor é o amadorismo, a ideia de que o verdadeiro desporto é alheio ao dinheiro e à profissionalização dos atletas. Gardiner foi profundamente influenciado pelo movimento amadorista do seu tempo e este preconceito reflecte- se claramente nos seus trabalhos, originando leituras distorcidas acerca do desenvolvimento do desporto grego.

A tese de Gardiner é baseada no pressuposto, provavelmente falso, de que nos primeiros tempos das competições desportivas todos os atletas eram amadores aristocratas, praticando o desporto pelo desporto e não recebendo quaisquer recompensas materiais pelas vitórias. No entanto, David Young tem provado precisamente o contrário: os primeiros atletas gregos não eram todos idealistas, aristocratas e verdadeiros amadores. Mais ainda, desde o início das competições desportivas, todos os atletas gregos, independentemente da sua origem social, esperavam e aceitavam prémios materiais pela sua vitória.( ${ }^{9}$ ) Assim, o amadorismo, entendido como a prática de um desporto sem dele auferir ganhos materiais ou financeiros, é algo que nunca existiu plenamente nos concursos desportivos da Grécia antiga(10). Já no Poemas Homéricos (M) a elite aristocrata recebia prémios valiosos pelas suas vitórias nas competições desportivas.

A especialização dos atletas, os substanciais prémios monetários e o profissionalismo não foram um novo fenómeno do século V. É por volta de 700 ou 680 a.C. que começa a desenvolver-se na Grécia o desporto de alta competição e a consequente especialização dos atletasO²). $\mathrm{O}$ treino físico intensivo, destinado à participação (e à vitória) nos Jogos,

(8) Desde meados dos anos 70 que as ideias de Gardiner têm sido postas em causa por vários autores, nomeadamente por H.W. Pleket, M.B. Poliakoff, mas sobretudo por D.C. Young, em 1984. Este autor considera que a absoluta dedicação de Gardiner ao amadorismo o levou a muitas interpretações erróneas acerca do desporto na Antiguidade.

(9) Young, "How amateurs won the Olympics", p.62: "All greek athletes from the start collected as much prize money as they could win."

(10) Finley-Pleket, em The Olympie Cames, p. 131, afirmam que "the 'true amateur' never existed in Antiquity".

("> llíada XXIII, 256 sgg.

(12) Vide Finley-Pleket, The Olympie Games, p.69, onde são referidas evidências da especialização dos atletas, nomeadamente o estatuto inferior do pentatlo e a raridade de duplas vitórias nas duas corridas de curta distância. 
torna-se progressivamente uma actividade exclusiva marcada pela especialização, e assim permanecerá até ao fim da Antiguidade.

Assim, muito antes do tempo de Pindaro, a crescente competição nos grandes Jogos levou ao desenvolvimento do desporto para além da esfera do puro exercício físico e da recriação, até que a prática do desporto se tornou, para muitos atletas, num fim em si mesmo. A especialização progrediu rapidamente nas mãos de treinadores profissionais, cujo negócio era treinar atletas para vencer nos Jogos pan-helénicos. Para muitos dos competidores, a prática do desporto torna-se uma ocupação exclusiva e especialmente orientada para alcançar a vitória nos concursos atléticos.

Estas vitórias não significavam apenas que o vencedor seria honrado como herói com estátuas e epínícios, mas significavam também que seria materialmente recompensado. A asserção de Gardiner de que é em consequência do aparecimento de prémios monetários que se inicia, no séc. IV a.C., o declínio e a corrupção nas competições desportivas implica que teria havido tempos anteriores em que recompensas materiais eram algo alheio aos Jogos. No entanto, parece que recompensas financeiras ou, pelo menos, presentes valiosos estiveram desde sempre associados ao reconhecimento das vitórias desportivas^3).

Embora nos Jogos pan-helénicos o prémio, oficialmente, fosse apenas uma coroa de folhagem, esses prémios simbólicos não eram necessariamente indicadores de amadorismo por parte dos atletas. Desde cedo surgiram benefícios oficiais da cidade natal para os vencedores nos Jogos sagrados, de tal forma que uma vitória olímpica ou ístmica significava também um considerável ganho financeiro. A partir de finais do século VII a.C., pelo menos, os vencedores nos Jogos sagrados recebiam das suas cidades recompensas oficiais pelas coroas pan-helénicas. Sólon, por exemplo, oferecia uma recompensa de 500 dracmas a qualquer ateniense que vencesse nos Jogos OlímpicosO4). Mas, além de competirem nos quatro Jogos pan- helénicos, os atletas gregos participavam em muitos outros concursos desportivos, de prestígio inferior, em que o prémio consistia numa abundante soma de dracmas.

(13) Cf. Pindaro, Xo Ode Nemeia, v. 44 sgg.

(14) Plutarco, Vida de Sólon, 23.2. 
Vários historiadores, nomeadamente Pleket e David YoungO ${ }^{5}$ ), chamam a atenção para um aspecto relevante: não havia, na Antiguidade grega, desaprovação do facto de atletas de sucesso receberem prémios materiais pelas suas vitórias. Alguns filósofos gregos, como XenófanesO6) e Sócrates, queixavam-se da atenção e riqueza que os vencedores recebiam, mas nunca questionaram a integridade dos atletas ou o direito a auferirem lucro das suas capacidades desportivas. A ideia, amadorista e moderna, de que um atleta não deve lucrar financeiramente com a prática do seu desporto parece ter sido alheia à mentalidade grega.

Ao contrário do que Gardiner pressupunha, a participação de atletas profissionais nas competições desportivas não é um fenómeno tardio nem resultante da multiplicação de atletas das classes sociais mais baixas. De facto, encontramos alguns atletas profissionais já desde a época arcaica. Mais ainda, Pleket deixa claro que é entre os aristocratas que vamos encontar os primeiros participantes profissionais.(17) Um dos atletas profissionais mais célebres da época arcaica é Milão de Crotona (séc. VI a.C.), cuja carreira se estendeu, pelo menos, durante vinte e quatro anos ao nível da alta competição(18).

A partir do momento em que os atletas aristocratas começam a contratar treinadores especializados^^${ }^{\wedge}$ ) para melhorar as suas capacidades físicas, torna-se cada vez mais difícil para um amador conseguir vencer nos concursos pan-helénicos. Quando as competições desportivas aumentam o nível de exigência, a participação nos grandes Jogos quase se torna monopólio dos atletas profissionais, que podem dispender do tempo e dinheiro necessários para adquirir a excelência física. Depois de o profissionalismo se instalar definitivamente nos

(15) The Olympie myth of Greek amateur athletics, p.91 : 'The amateur policy forbidding all athletic profit was as fooreign to archaic greek athletics as it was to the professionals of later days."

(lé) Frg. 2 Diels. Xenófanes, no século VI a.C., refere que os atletas vencedores eram alimentados a expensas públicas e recebiam uma dádiva valiosa (vv. 8- 9).

(17) Pleket, "The participants in the ancient Olympie games: social background and mentality", p. 148.

(18) Pausanias, Descrição da Grécia, VI. 14.5.

(19) Pindaro, nas suas odes, menciona alguns treinadores: Menandro (Nemeias, V), Orseas (ístmicas, III), lias (Olímpicas, XI), Melesias (Olímpicas, VIII; Nemeias, VI). 
concursos desportivos, o atleta amador já não consegue competir com o profissional.

Teógenes de Taso, que viveu na primeira metade do século $V$ a.C., é o exemplo mais célebre de atleta profissional. Segundo o relato de Pausânias(20), Teógenes, ao longo dos vinte e dois anos da sua carreira, terá conseguido 1400 vitórias. É claro que este número é exagerado e mítico, sinal de heroicização do atleta, mas talvez possamos admitir que Teógenes tenha ganho, em média, uma vitória por semana. Este exemplo não é necessariamente excepcional. Nas odes de Pindaro encontramos certos paralelos, ainda que poéticos: alguns dos seus heróis ganharam "inumeráveis" vitórias, ou "vitórias tão numerosas quanto os grãos de areia da praia". Para um atleta como estes, o desporto deixara de ser uma mera recriação e passara a ser o seu modo de vida.

Podíamos, com alguma pertinência, perguntar porque é que, a contrastar com a ideologia de Coubertin e de outros olimpistas, nunca houve um movimento na Antiguidade para banir o profissionalismo e as recompensas monetárias das competições desportivas. De facto, este é um fenómeno bastante recente, já que apenas no século XIX se tornou aristocrático separar o dinheiro da prática do desporto. Pleket dá uma resposta possível para esta questão: na Antiguidade, a aristocracia nunca deixou de aceitar recompensas monetárias pelas suas vitórias atléticas, porque a sua posição social nunca esteve verdadeiramente ameaçada por uma classe de comerciantes que, aos olhos dos aristocratas, não passavam de novos-ricos sem pergaminhos sociais.(2l) Esta mudança económica e social desenvolveu-se no século XIX e tornou-se o principal factor que levou aos inícios do movimento amadorista, nascido entre a classe aristocrata da Inglaterra vitoriana.

Embora na Antiguidade nunca tivesse havido uma tentativa para impedir a participação de atletas profissionais nas competições desportivas, os protestos contra o profissionalismo no desporto não são um fenómeno moderno. Encontramos já em certos autores gregos duras críticas contra a profissionalização dos atletas. E o caso de Eurípides(22)

(29) Descrição da Grécia, VI. I 1.5.

(21) Pleket, "Games, prizes, athletes and ideology: some aspects of the history of sport in Greco- Roman world", p.87 sgg.

(22) Autolykos, frg 282 (apud Ateneu 10.413) 
e, séculos mais tarde, de Galenoí23) e Filóstratoí ${ }^{24}$ ). Os protestos destes autores testemunham que a Grécia antiga não foi a idade ideal do amadorismo olímpico.

No inicio do novo milénio, uma nova pergunta se levanta: com a recente desmistificação do mito do amadorismo grego, faz ainda hoje sentido pugnar pelo "regresso" do espírito olímpico moderno ao ideal de amadorismo proposto por Pierre de Coubertin?

\section{BIBLIOGRAFIA}

FINLEY, M.I. and PLEKET, H.W., The Olympie Cames. The first thousand years. London/New York, 1976.

GARDINER, E.N., Creek Athletic Sports and Festivais. Handbooks of Archaeology and Antiquities. London, Macmillan, 1910.

GARDINER, E.N., Athlètes of the Ancient World. Oxford, Clarendon Press, 1930.

KYLE, D.G., "E. Norman Gardiner and the decline of Greek sport" in Kyle (ed.) Essays on sport history and sport mythology. Arlinghton, 1990, pp.7- 44.

MILLER, S.G., Arete. Creek sports from ancient sources. Berkeley, 1991.

PLEKET, H.W., "Games, prizes, athletes and ideology: some aspects of the history of sport in the Graeco- Roman world", Stadion I, 1975, pp.49-89.

PLEKET, H.W., "The participants in the ancient Olympie games: social background and mentality", in Coulson and Kyrieleis (eds.), Proceedings of an international symposium on the Olympie Cames (5- 9 September 1988). Athens, 1992, pp. 147- 152.

POLIAKOFF, Michael, Combat Sports in the Ancient World. Compétition, violence and culture. Yale University Press, 1987.

SWEET, Waldo, Sport and Recriation in Ancient Creece. Oxford University Press, 1987.

WEBER, E., "Pierre de Coubertin and the introduction of organised sport", in Weber, NIy France. Cambridge Mass, 1991, pp.207-225.

YOUNG, D.C., "How amateurs won the Olympics" in W.J. Raschke, The Archaeology of the Olympics. The Olympics and other festivals in Antiquity. Madison, Wisconsin, 1988.

YOUNG, D.C., The Olympie myth of Creek amateur athletics. Chicago, 1984.

<23) Exortação à medicina, 9- 14.

(24) Da Cinàstica, 45. 